\title{
Central and Peripheral Neurite Outgrowth Differs in Preference for Heparin-Binding versus Integrin-Binding Sequences
}

\author{
Patricia K. Haugen, ${ }^{1}$ James B. McCarthy, ${ }^{2}$ Kokila F. Roche, ${ }^{1}$ Leo T. Furcht, ${ }^{2}$ and Paul C. Letourneau' \\ Departments of ${ }^{1} \mathrm{Cell}$ Biology and Neuroanatomy and ${ }^{2}$ Laboratory Medicine and Pathology, University of Minnesota, \\ Minneapolis, Minnesota 55455
}

\begin{abstract}
Neurons of the CNS and PNS differ in their response to fibronectin (FN) and proteolytic fragments of FN. The $33 \mathrm{kDa}$ $\mathrm{C}$-terminal cell and heparin-binding fragment of $\mathrm{FN}$, in particular, is a strong promoter of CNS neurite outgrowth. To define further the neurite-promoting activity of the $33 \mathrm{kDa}$ fragment, and to investigate further the differences between PNS and CNS responses to $\mathrm{FN}$ and the $33 \mathrm{kDa}$ fragment, we contrasted neurite outgrowth by CNS and PNS neurons on three synthetic peptides representing sequences from this fragment of $\mathrm{FN}$ : two heparin-binding peptides, $\mathrm{FN}-\mathrm{C} / \mathrm{H} \mathrm{I}$ and $\mathrm{FN}-\mathrm{C} / \mathrm{H}$ II (McCarthy et al., 1990), and an integrin-binding peptide, CS1 (Humphries et al., 1987). Spinal cord (SC) neurons, from the CNS, differed from dorsal root ganglion (DRG) neurons, from the PNS, with respect to substratum preference for heparin-binding versus integrin-binding peptides. SC neurite outgrowth was greatest on the heparin-binding peptide FN-C/H II, while DRG neurite outgrowth was greatest on the a481 integrin-binding peptide CS1. To test whether the difference in substratum preference was due to differences in the molecular mechanism by which SC and DRG neurons interact with the $33 \mathrm{kDa}$ fragment of $\mathrm{FN}$, anti- $\beta 1$ integrin antibodies and/or soluble heparin were added to the cultures as potential inhibitors of integrin-mediated or proteoglycan-mediated interactions with FN. SC neurite outgrowth was much more sensitive to the effect of heparin than anti- $\beta 1$ integrin, indicating SC neurite outgrowth may involve predominantly a heparin-sensitive mechanism. In contrast, DRG neurite outgrowth was more sensitive to anti$\beta 1$ integrin, but also affected by heparin, indicating DRG neurite outgrowth involves predominantly a $\beta 1$ integrin-mediated mechanism with some contribution by a heparin-sensitive mechanism.
\end{abstract}

\footnotetext{
Received June 19, 1991; revised Dec. 23, 1991; accepted Jan. 6, 1992.

We thank the following for their contributions to this rescarch: Dr. Alan Horwitz (University of Illinois, Champaign-Urbana) for generously contributing the W1B10 antibody, Vicki VanDisse for purification of the synthetic peptides, and Drs. Irene Pech and Julie Lesser for preliminary studies that inspired this work. This research was supported by Predoctoral Graduate Research Training Fellowship 18-FY911029 from the March of Dimes Birth Defects Foundation (P.K.H.), an Elsa Pardee grant (J.B.M.), grants from the American Paralysis Association (P.C.L. and I.B.M.), and Leukemia Task Force (J.B.M. and L.T.F.), and the following NIH grants: HD-19950, NS-28807 (P.C.L), CA-43924 (J.B.M), EY-06625, and CA-21463 (L.T.F). This report was submitted by P.K.H. in partial fulfillment of the requirements for a Ph.D. from the graduate school of the University of Minnesota.

Correspondence should be addressed to Patricia K. Haugen, Department of Pathology, Washington University School of Medicine, Box 8118,660 South Euclid Avenue, St. Louis, MO 63110.

Copyright (C) 1992 Society for Neuroscience $0270-6474 / 92 / 122034-09 \$ 05.00 / 0$
}

Neurite outgrowth is a dynamic process involving interactions of the migrating neurite tip, the growth cone, with extrinsic adhesive ligands and other factors in such a manner that growing neurites follow characteristically appropriate pathways (Letourneau, 1985, 1989; Gunderson, 1987; Dodd and Jessell, 1988; Sanes, 1989; Reichardt and Tomaselli, 1991). The formation of a neurite depends, in part, on interactions of cell surface molecules with extracellular matrix (FCM) components. One of the many ECM components able to provide a substratum for neurite outgrowth in vitro is fibronectin (FN) (Akers et al., 1981; Carbonetto et al., 1983; Rogers et al., 1983, 1985, 1989; Hall et al., 1987). FN is spatially and temporally expressed in both the developing CNS and PNS in an appropriate manner for a role in neurite outgrowth and neuronal migrations (Duband and Thiery, 1982a,b; Bronner-Fraser, 1986; Stewart and Pearlman, 1987; Chun and Shatz, 1988; Dufour et al., 1988).

Cellular responses to $\mathrm{FN}$ involve multiple sequences within the FN molecule. A $75 \mathrm{kDa}$ proteolytic fragment of FN containing at least two cell-binding sequences, including the arginylglycyl-asparagyl-serine (RGDS) sequence, promotes adhesion of several cell types, as well as PNS neurite outgrowth (Pierschbacher and Ruoslahti, 1984; Rogers et al., 1985, 1987; McCarthy et al., 1986; Waite et al., 1987; Letourneau et al., 1988; Mugnai et al., 1988; Ohara et al., 1988; Lewandowska et al., 1990). A $33 \mathrm{kDa}$ carboxy-terminal cell and heparin-binding fragment of $\mathrm{FN}$ differs from the $75 \mathrm{kDa}$ fragment in that it strongly promotes not only PNS, but also stable CNS neurite outgrowth (Rogers et al., 1985, 1987). In addition, this fragment of FN promotes the RGD-independent adhesion and spreading of several other cell types (Izzard et al., 1986; McCarthy et al., 1986, 1988, 1990; Liao et al., 1989; Visser et al., 1989; Wayner et al., 1989; Mould et al., 1990). A synthetic peptide approach has identified multiple sequences in the $33 \mathrm{kDa}$ cell and heparinbinding fragment that promote cell adhesion and are important for cellular interactions with this region: CS1 (Humphries et al., 1987, 1988; McCarthy et al., 1988, 1990; Wayner et al., 1989; Guan and Hynes, 1990; Haugen et al., 1990; Mould et al., 1990), FN-C/H I (YEKPGSPPREVVPRPRPGV; McCarthy et al., 1988, 1990), and FN-C/H II (KNNQKSEPLIGRKKT; McCarthy et al., 1988; Haugen et al., 1990). FN-C/H I and FN$\mathrm{C} / \mathrm{H}$ II differ from CS1 in that they bind heparin in solid-phase assays (McCarthy et al., 1988), and cell adhesion to these sequences is inhibited by the addition of exogenous heparin (Haugen et al., 1990; McCarthy et al., 1990). In addition to promoting cell adhesion, the CS1 sequence promotes PNS neurite outgrowth (Humphries et al., 1988). The effects of FN-C/H I or 


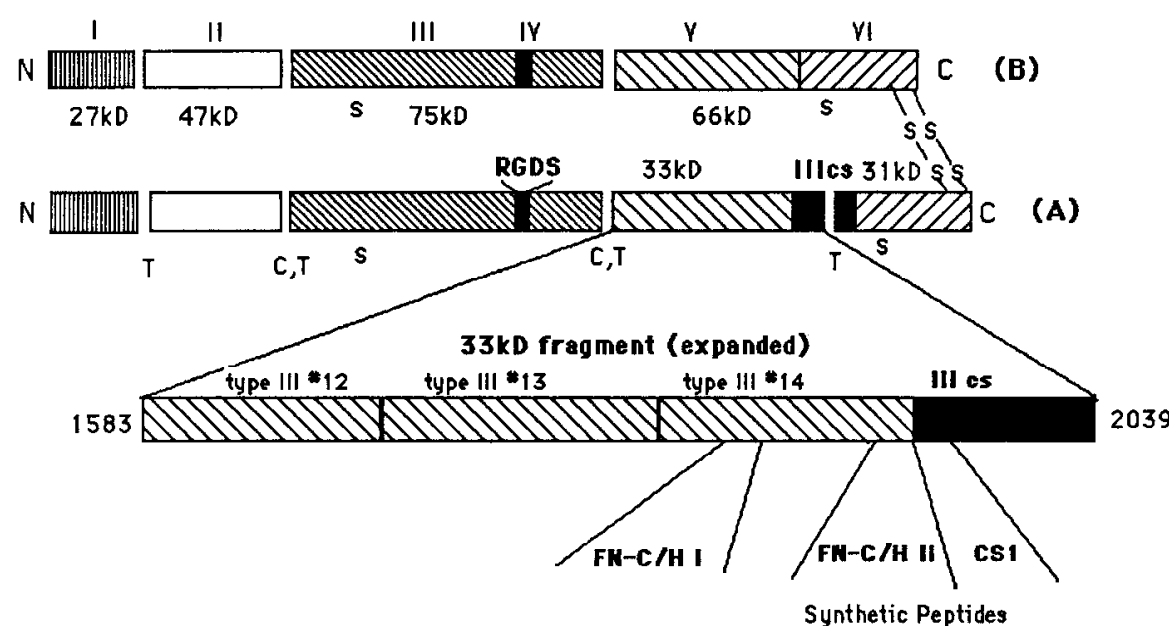

Synthetic Peptides
Figure 1. Location of the $33 \mathrm{kDa}$ and $66 \mathrm{kDa}$ heparin-binding fragments and the synthetic peptide sequences within the intact fibronectin molcculc. Also depicted is the location of the IIIcs region found only on the A-isoform of human plasma fibronectin: The amino and carboxyl ends of the $33 \mathrm{kDa}$ fragment are based on previous sequence data (McCarthy et al., 1988). Selected biological domains, indicated by roman numerals at the top, are based on the nomenclature of Furcht (1981). I, weak heparin binding; $I I$, collagen binding; $I I I$, free sulfhydryl $(S) ; I V$, RGD-mediated cell adhesion; $V$, carboxyl-terminal strong heparin binding and cell adhesion; VI, free sulfhydryl. Location of tryptic ( $T$ ) and cathepsin D (C) sites on fibronectin are shown.
FN-C/H II on primary neurite outgrowth have not been previously reported.

To interact with the multiple cell adhesion sequences in $\mathrm{FN}$, cells make use of multiple receptors on their surfaces. One major class of cell surface receptors for FN is the $\beta 1$ integrin family, members of which bind the RGDS sequence (a5 $\beta 1$ integrin: Horwitz et al., 1985; Pytela et al., 1985), the CS1 sequence (a4 $\beta 1$ integrin: Wayner et al., 1989; Guan and Hynes, 1990; Mould et al., 1990), and additional unidentified sequences in FN (for review, see Buck and Horwitz, 1987; Hynes, 1987; Ruoslahti, 1988a; Yamada, 1989; Dedhar, 1990; Humphries, 1990; Reichardt and Tomaselli, 1991). A role for $\beta 1$ integrins in neurite outgrowth is suggested by the expression of $\beta 1$ integrin on developing neurons (Bozyczko and Horwitz, 1986; Tomaselli et al., 1988; Letourneau and Shattuck, 1989). A second class of molecules that interact with matrix components, including FN, are cell surface proteoglycans (Laterra et al., 1983; Rapraeger and Bernfield, 1983; Saunders and Bernfield, 1988; LeBaron et al., 1989; for revicw, scc Ruoslahti, 1988b; Reichardt and Tomaselli, 1991). A likely possibility is that cells interact with the heparin-binding sequences in FN using cell surface proteoglycans. Several forms of proteoglycans have been isolated from the CNS, some of which are developmentally regulated and present during periods of CNS neurite outgrowth (Margolis and Margolis, 1989; Zaremba et al., 1989; Herndon and Lander, 1990), suggesting that proteoglycans may also play important roles in neurite outgrowth.

It is clear that CNS and PNS neurons differ with respect to their interactions with FN (Rogers et al., 1985, 1987). However, the molecular basis for this difference is poorly defined. Additionally, little is known of the molecular basis for neurite outgrowth on the $33 \mathrm{kDa}$ carboxy-terminal cell and heparin-binding fragment of FN, which is a strong promoter of neurite outgrowth. The present study was designed to further define neuritepromoting sequences within the $33 \mathrm{kDa}$ fragment of FN using the synthetic peptides named above, and to compare PNS and CNS responses to these sequences. We further investigated differences between CNS and PNS neurons using inhibitors of cell surface $\beta 1$ integrins and heparin-like proteoglycan molecules that may mediate neurite outgrowth. Our data demonstrate a clear difference between CNS and PNS neurons in both their FN sequence preference and in their sensitivity to these inhibitors. In general, CNS neurite outgrowth was more extensive on heparin-binding ligands, while PNS neurite outgrowth was greater on integrin-binding ligands. We propose that CNS and PNS neurons use different cell surface molecules for the adhesive interactions that mediate neurite elongation on FN.

\section{Materials and Methods}

Protein, fragment, and peptide preparation. Human plasma FN was purified as a byproduct of Factor VIII production by sequential ion exchange and gelatin affinity chromatography as described previously (McCarthy et al., 1986). A 2 min trypsin digest followed by a cathepsin D digest produced the $75 \mathrm{kDa}$ and $33 / 66 \mathrm{kDa}$ fragments as described previously (McCarthy et al., 1986; for location, see Fig. 1).

Peptides were synthesized at the University of Minnesota Microchemical Facility using a peptide synthesizer (System 990, Beckman Instruments, Fullerton, CA), using a procedure based on the Merrifield solid-phase system (Stewart and Young, 1984), as described previously (McCarthy et al., 1988; Haugen et al., 1990). Peptides were purified and their composition verified as described previously (McCarthy et al., 1988; Chelberg et al., 1989; Haugen et al., 1990). The FN peptides specifically used for this study are (for location, see Fig. 1) FN-C/H I, representing residues 1906-1924 (YEKPGSPPREVVPRPRPGV); FNC/H II, representing residues 1946-1960 (KNNQKSEPLIGRKKT; based on sequence information from Kornblihtt et al., 1985); and CS1, with a primary sequence of DELPQLVTLPHPNLHGPEILDVPST (Humphries et al., 1987). The sequences shown use the single letter amino acid code $(\mathrm{K}=$ lysine, $\mathrm{R}=$ arginine, $\mathrm{H}=$ histidine, $\mathrm{E}=$ glutamic acid, $\mathrm{D}=$ aspartic acid, $\mathrm{Q}=$ glutamine, $\mathrm{N}=$ asparagine, $\mathrm{P}=$ proline, $\mathrm{G}=$ glycine, $\mathrm{S}=$ serine, $\mathrm{T}=$ threonine, $\mathrm{V}=$ valine, $\mathrm{I}=$ isoleucine, $\mathrm{L}=$ leucine, $\mathrm{Y}=$ tyrosine).

Synthetic peptides were coupled to ovalbumin (OA), as suggestcd by Humphries et al. (1987), based on a procedure by Bauminger and Wilchek (1980). Briefly, equal amounts (by weight) of peptide and ovalbumin were solubilized and mixed with a 10 -fold excess (by weight) of 1-ethyl-3-(3-dimethylaminopropyl)-carbodiimide hydrochloride (Sigma Chemical, St. Louis, MO), dissolved in water. After mixing overnight at $4^{\circ} \mathrm{C}$, the sample was extensively dialyzed in PBS to remove excess carbodiimide and uncoupled peptide (10,000 Da exclusion, Spectrum Medical Industries, Los Angeles, CA). The stoichiometry of peptide coupling was $2.9 \mathrm{~mol}$ of $\mathrm{FN}-\mathrm{C} / \mathrm{H}$ II to $1 \mathrm{~mol}$ of OA, with an efficiency of about $11 \% ; 5.3 \mathrm{~mol}$ of $\mathrm{FN}-\mathrm{C} / \mathrm{H}$ I to $1 \mathrm{~mol}$ of OA, $24 \%$ efficiency; and $6.3 \mathrm{~mol}$ of CS1 to $1 \mathrm{~mol} \mathrm{OA}, 39 \%$ efficiency, as described previously (Haugen et al., 1990).

Cell culture. Dorsal root ganglia (DRG) from embryonic day 12 (E12) or spinal cords (SC) from E8 Whitc Leghorn chicks were dissected, and the cells dissociated by a 20 min incubation in $0.25 \%$ trypsin followed by gentle trituration. Cells were washed twice in $10 \%$ serum medium, and then cultured in serum-free defined media in 96 well Immulon-1 plates that had been coated overnight with the appropriate substratum. Serum-free (defined) medium was composed of F14 (GIBCO, Grand Island, NY) buffered with bicarbonate, to which the following were added: insulin $(5 \mu \mathrm{g} / \mathrm{ml})$, phosphocreatine $(5 \mathrm{~mm})$, sodium selenite (5 


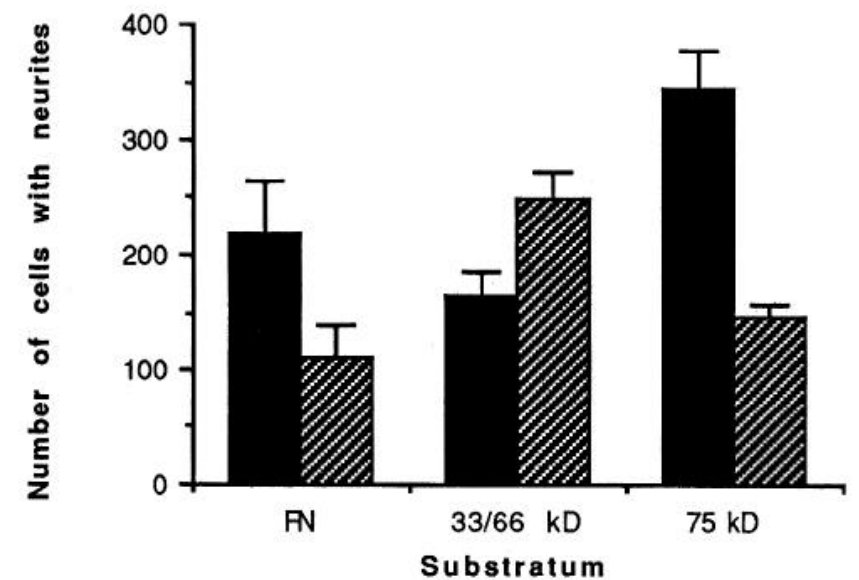

Figure 2. Neurite outgrowth by peripheral and central neurons on FNderived substrata. Chick DRG neurons (solid bars) or SC neurons (hatched bars) were cultured on substrata treated with $0.5 \mu \mathrm{M}$ concentrations of $\mathrm{FN}$, a mixture of the $33 \mathrm{kDa}$ and $66 \mathrm{kDa}$ C-terminal heparin-binding fragments from FN A- and B-chains, or the $75 \mathrm{kDa}$ fragment containing the RGDS sequence. The substratum coating concentration was determined from a concentration curve to be one that promoted maximum neurite outgrowth on each of these substrata. Maximum neurite outgrowth represents at least $50 \%$ of the total cells inoculated into the culture. Neurite outgrowth was determined by visual counting. The data shown represent the average of three separate determinations, \pm SEM.

$\mathrm{ng} / \mathrm{ml})$, transferrin $(0.1 \mathrm{mg} / \mathrm{ml})$, sodium pyruvate $(0.4 \mathrm{mg} / \mathrm{ml})$, and progesterone ( $20 \mathrm{nM}$ ), all purchased from Sigma (St. Louis, MO), and $\beta$-NGF $(15 \mathrm{ng} / \mathrm{ml}$, a generous gift of Dr. Bernard Mirkin, University of Minnesota).

Neurite assays. Substrata were prepared by adsorbing FN, proteolytic fragments of FN, and synthetic peptides, which had been diluted to the appropriate concentrations in Voller's carbonate buffer, to Immulon-1 plates, and, subsequently, nonspecific sites were blocked by addition of a solution of $5 \mathrm{mg} / \mathrm{ml}$ of bovine serum albumin (BSA; fatty acid free, Miles, Naperville, IL) in Dulbecco's phosphate-buffered saline (DPBS) for $2-3 \mathrm{hr}$ as described previously (Haugen et al., 1990). Prior to the addition of cells, the substrata were rinsed three times with DPBS. Chick DRG or SC neurons were resuspended at 40,000 cells/ml (DRGs) or
$60,000 \mathrm{cells} / \mathrm{ml}$ (SC), and $100 \mu \mathrm{l}$ were added to each well. Cells were allowed to extend neurites for $24 \mathrm{hr}$ at $37^{\circ} \mathrm{C}$ in $5 \% \mathrm{CO}_{2}$. Adherent cells were fixed with $2 \%$ glutaraldehyde for $20-40 \mathrm{~min}$ and counted using phase-contrast microscopy with a $10 \times$ objective on a Nikon inverted scope. Cells observed in one diameter across each well, 3.5 fields of view (approximately $20 \%$ of the total area of each well), were counted. Neurons were identified according to morphology as having round, phase-bright cell bodies, and scored as having neurites if there was at least one process greater than the cell diameter.

Inhibition assays. Substrata and cells were prepared as described above. For peptide or antibody inhibition assays, cells were cultured for $24 \mathrm{hr}$ on the appropriate substrata in media containing either the indicated concentration of soluble peptide or $20 \mu \mathrm{g} / \mathrm{ml}$ of purified W1B10 IgG, which recognizes the chicken $\beta 1$ integrin subunit (a generous gift of Dr. A. Horwitz, University of Illinois, Champaign-Urbana), respectively. For heparin inhibition assays, the substratum was preincubated for 1 hr with $10 \mu \mathrm{g} / \mathrm{ml}$ soluble heparin (Sigma Chemical Co., St. Louis, MO) at $37^{\circ} \mathrm{C}$, after which time the nonbound heparin was removed by three rinses in PBS. Cells were then added to the substratum, pretreated with heparin, and cultured for $24 \mathrm{hr}$ in defined medium or defined medium plus W1B10 antibody (for additive heparin + antibody inhibition experiments). In all cases, neurite outgrowth was assayed by counting fixed cells, as described above.

\section{Results}

\section{PNS and CNS neurite outgrowth differs in substratum preference}

Previous studies suggested that central and peripheral neurons differ in their responses to FN (Rogers et al., 1983, 1985, 1987). To investigate further such differences, sensory DRG neurons from the PNS and SC neurons from the CNS were dissociated and cultured on FN-derived substrata to compare their responses. Substrata were treated with equimolar concentrations of FN or two tryptic fragments of FN: a $75 \mathrm{kDa}$ fragment containing the RGDS sequence, or a mixture of the $33 \mathrm{kDa}$ and 66 $\mathrm{kDa}$ fragments derived from the C-terminal heparin-binding region of FN A-chains and B-chains, respectively (Fig. 1). DRG and SC neurons differed in their responses to these three substrata. DRG neurite outgrowth was greatest on the $75 \mathrm{kDa}$ fragment, while SC neurite outgrowth was greatest on the 33/66 $\mathrm{kDa}$ fragments (Fig. 2). Substrata treated with either FN or the
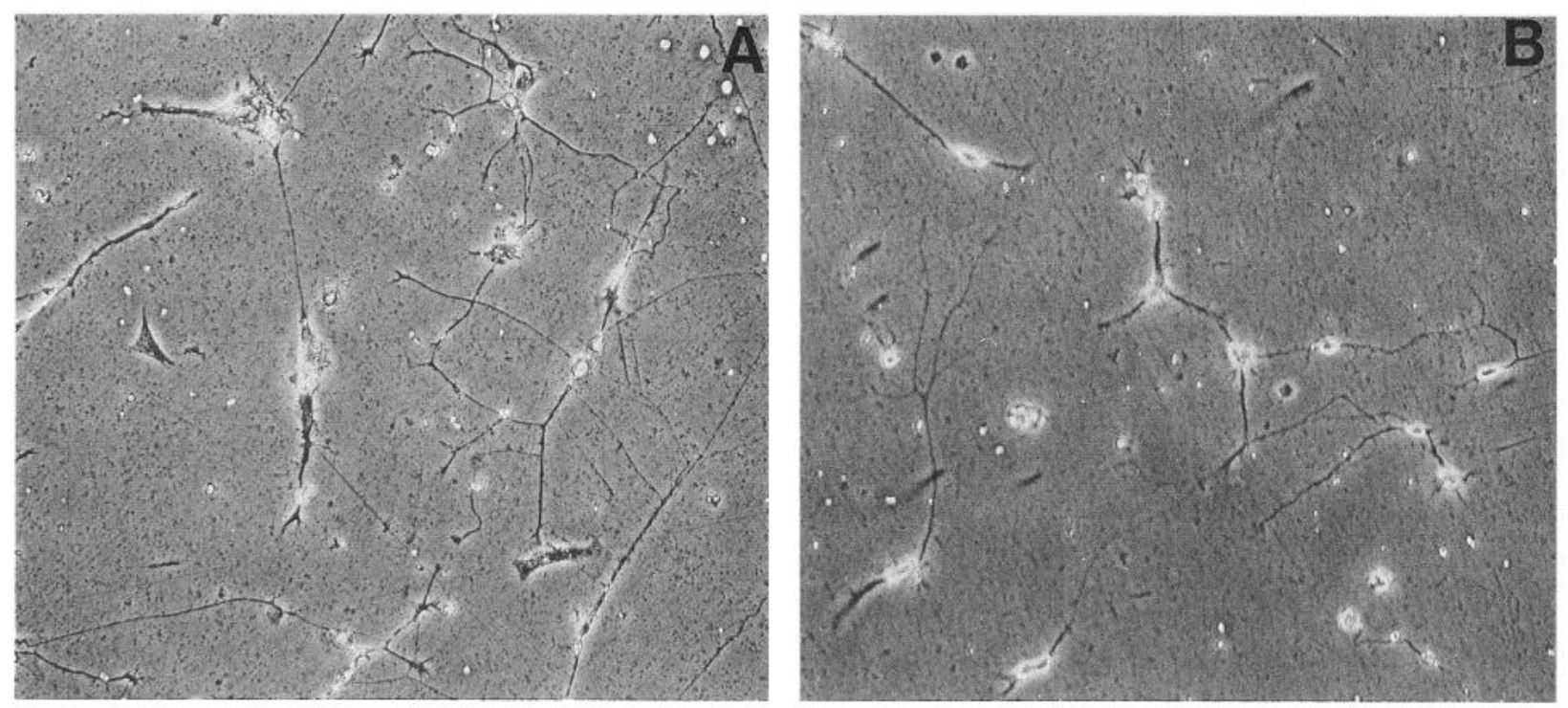

Figure 3. Light micrographs of DRG neurons $(A)$ and SC neurons $(B)$ extending neurites after $24 \mathrm{hr}$ on plastic treated with the $33 / 66 \mathrm{kDa}$ heparinbinding fragment of FN. Note that few non-neuronal cells are present, and neurites are clearly visible extending directly on the substratum. Neuronal morphologies are not significantly different when DRG or SC neurons are cultured on substrata treated with the other FN fragments or synthetic peptides. $400 \times$. 
$75 \mathrm{kDa}$ fragment were more effective at promoting DRG neurite outgrowth than SC neurite outgrowth (Fig. 2). In contrast, substrata treated with the $33 / 66 \mathrm{kDa}$ heparin-binding fragments were more effective at promoting $\mathrm{SC}$ neurite outgrowth than DRG neurite outgrowth (Fig. 2). Using a soluble RGD-containing peptidc, we detcrmined, as expected from previous work (Rogers et al., 1987), that neurite outgrowth on the $75 \mathrm{kDa}$ fragment was totally RGD dependent (not shown). In these cultures, few non-neuronal cells were present, and neurites extended directly on the substratum, rather than on the surfaces of non-neuronal cells (Fig. 3).

In order to further define neurite-promoting sequences in the $33 / 66 \mathrm{kDa}$ cell and heparin-binding fragments of FN, we tested three synthetic peptides whose sequences are found in this region of FN for their neurite-promoting ability. Each peptide has been shown to support cell-substratum adhesion (for location in the FN sequence, see Fig. 1): FN-C/H I (McCarthy et al., 1988, 1990), FN-C/H II (McCarthy et al., 1988; Haugen et al., 1990), and CS1 (Humphries et al., 1987, 1988; Wayner et al., 1989; Haugen et al., 1990; McCarthy et al., 1990). $\mathrm{FN}-\mathrm{C} / \mathrm{H}$ I and $\mathrm{FN}-$ $\mathrm{C} / \mathrm{H}$ II both bind heparin, while CS1 does not (McCarthy et al., 1988). FN-C/H I and FN-C/H II are present in all isoforms of $\mathrm{FN}$, while CS1 is located within the alternatively spliced IIIcs region unique to $\mathrm{FN} A$-chains. In order to facilitate binding to the substratum, all peptides were conjugated to OA (Haugen et al., 1990).

Both SC and DRG neurons extended neurites on all three peptides in a concentration-dependent manner, but differed in their responses to low concentrations of each peptide. The minimum concentration of FN-C/H II-OA that induced SC neurite outgrowth was one-fifth of the minimum concentration required for DRG neurite outgrowth (Fig. $4 A$ ). Additionally, the maximum level of neurite outgrowth observed on FN-C/H II-OA was greater for SC neurons than for DRG neurons. In contrast, DRG neurons responded to significantly lower concentrations of CSl-OA than did SC neurons (Fig. 4B). Finally, SC and DRG neurite outgrowth on FN-C/H I-OA was similar at all concentrations (Fig. 4C). When the data from the different substrata were compared directly, neurite outgrowth by SC neurons was greatest on FN-C/H II-OA, while neurite outgrowth by DRG neurons was greatest on CS1-OA (not shown), indicating clear differences in substratum preference.

As an additional means to assess the relative role of each peptide in DRG and SC neurite outgrowth, the peptides were each added in solution as potential inhibitors that might compete with neurite outgrowth on the $33 / 66 \mathrm{kDa}$ fragments. DRG neurite outgrowth on the $33 / 66 \mathrm{kDa}$ fragments was inhibited to the greatest extent by soluble CS1, less effectively by soluble FN-C/H I, and least effectively by soluble FN-C/H II (Fig. $5 A$ ). In contrast, $\mathrm{SC}$ neurite outgrowth on the $33 / 66 \mathrm{kDa}$ fragments was significantly inhibited by soluble FN-C/H II, less effectively inhibited by soluble FN-C/H I, and virtually unaffected by soluble CS1 (Fig. 5B). These results parallel the different substratum preferences of DRG and SC neurons noted in Figure 4, suggesting that the differences in substratum preference between DRG and SC neurons relate to differences in their interactions with these peptide sequences within the $33 / 66 \mathrm{kDa}$ fragments.

Soluble heparin and anti- $\beta 1$ integrin antibodies have different effects on CNS and PNS neurite outgrowth

The preceding experiments demonstrate that DRG and SC neurons prefer to interact with different regions of the FN molecule,
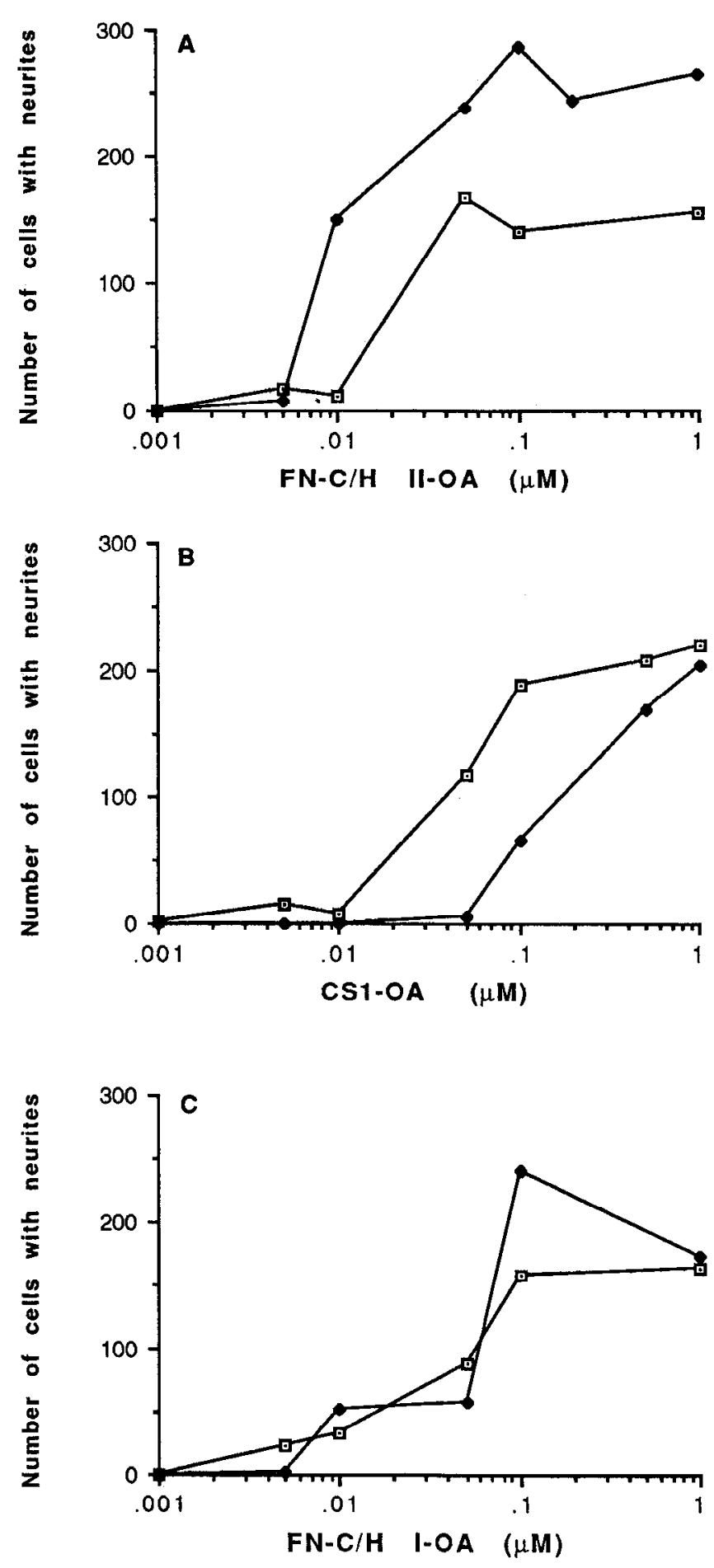

Figure 4. Neurite outgrowth by peripheral and central neurons on synthetic FN peptides. Chick DRG neurons (open squares) or SC neurons (solid diamonds) were cultured on increasing concentrations of FN$\mathrm{C} / \mathrm{H}$ II conjugated to ovalbumin (FN-C/H II-OA) $(A)$; CS1-OA $(B)$; $\mathrm{FN}-\mathrm{C} / \mathrm{H}$ I-OA $(C)$. Values represent the mean of triplicate determinations, with an SE less than $10 \%$. Maximum neurite outgrowth represents greater than $50 \%$ of the total cells inoculated into the cultures.

and different sequences within the $33 / 66 \mathrm{kDa}$ fragment. One possible explanation for these differences is that DRG and SC neurons differ in the cell surface components that mediate neuronal interactions with FN. To further define the nature of the cell surface molecules involved in neurite outgrowth on the 

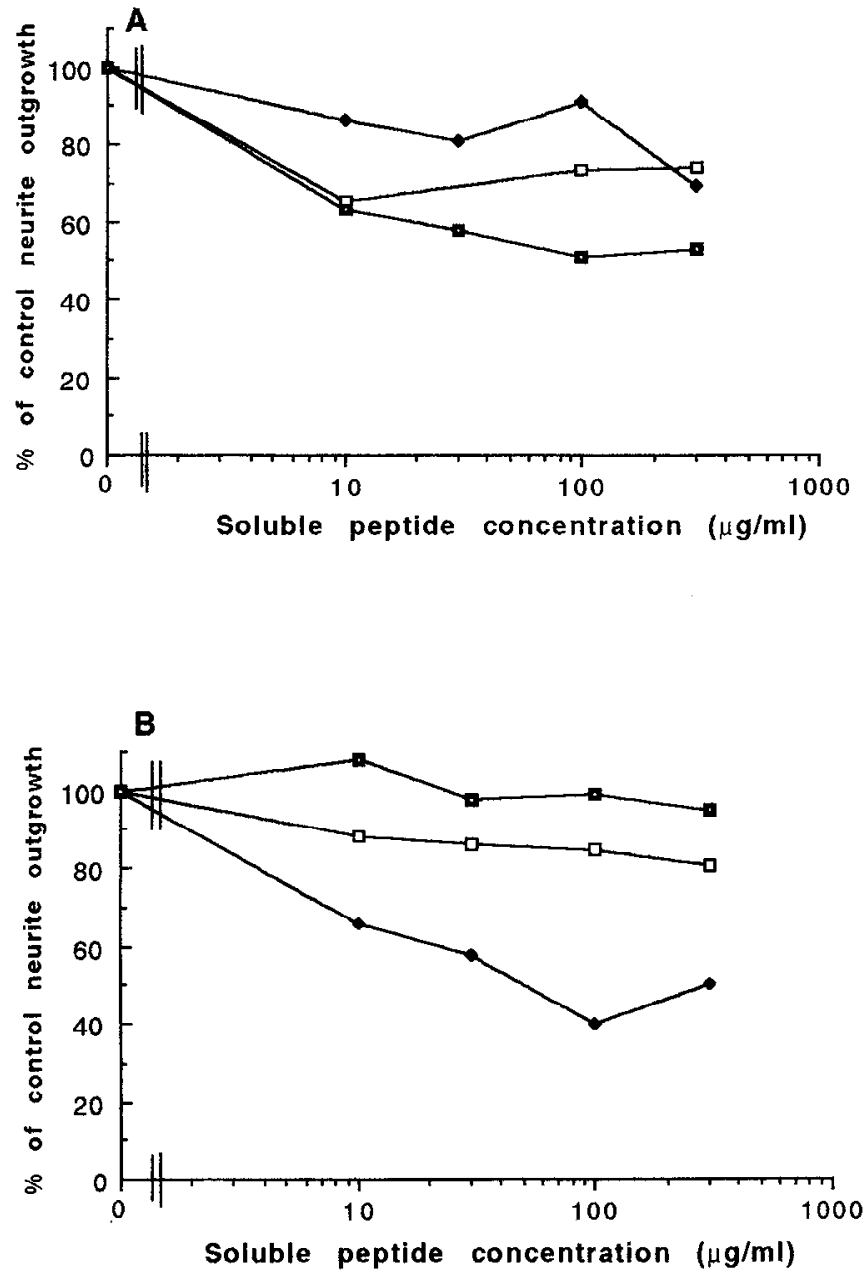

Figure 5. Effect of soluble FN peptides on neurite outgrowth. Chick DRG neurons $(A)$ or SC neurons $(B)$ were culturcd on substrata treatcd with $0.1 \mu \mathrm{M}$ concentrations of the $33 / 66 \mathrm{kDa}$ fragments. Increasing concentrations of CS1 (solid squares), FN-C/H I (open squares), or FN$\mathrm{C} / \mathrm{H}$ II (solid diamonds) were added to the cultures at the time of inoculation. Neurite outgrowth was quantitated by visual counting and is expressed relative to the level of neurite outgrowth observed in control cultures to which no soluble peptide had been added. Values represent the mean of triplicate determinations. Control neurite outgrowth levels were similar to those in Figure 2.

C-terminal cell and heparin-binding region, substrata were pretreated with exogenous heparin as a potential competitive blocker of a cell surface heparin-like proteoglycan that may mediate neuron-to-substratum adhesion and neurite outgrowth. For both $\mathrm{SC}$ and DRG neurons, pretreatment of the substratum with heparin most effectively inhibited neurite outgrowth on FNC/H II-OA treated substrata (Fig. 6), consistent with previous results that ccll adhesion to $\mathrm{FN}-\mathrm{C} / \mathrm{H}$ II is heparin sensitive (Haugen et al., 1990). Heparin also inhibited neurite outgrowth on the other heparin-binding peptide, FN-C/H I-OA. Inhibition by heparin on $\mathrm{FN}-\mathrm{C} / \mathrm{H}$ I-OA was partial for DRG neurite outgrowth and virtually complete for SC neurite outgrowth (Fig. 6). Heparin had little effect on neurite outgrowth on CS1-OA.

In all cases, $\mathrm{SC}$ neurons were more sensitive to the effects of heparin than were DRG neurons. SC neurite outgrowth was inhibited by heparin on substrata treated with the $33 / 66 \mathrm{kDa}$ fragments or intact FN. In contrast, DRG neurite outgrowth was unaffected by heparin on both of these substrata (Fig. 6).

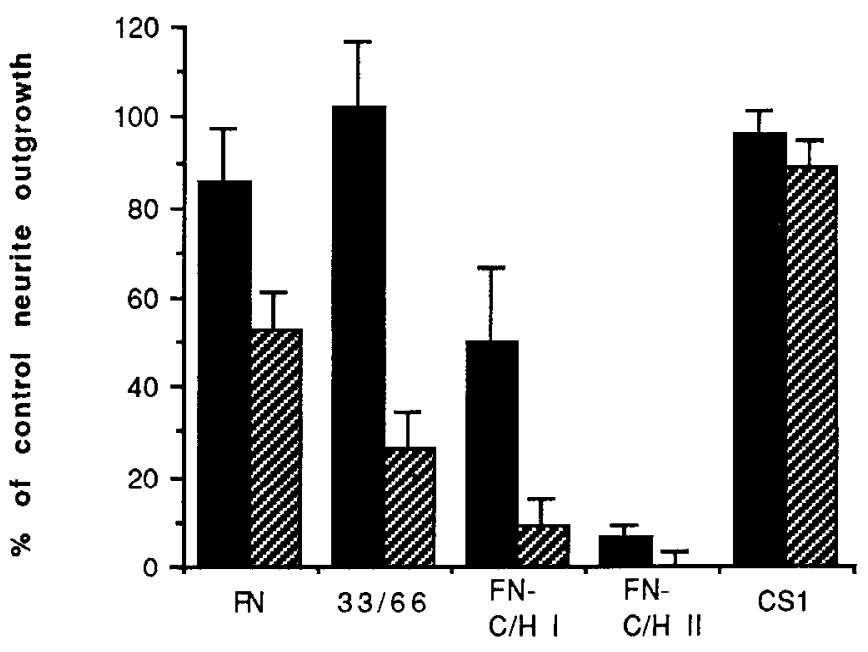

Figure 6. Effect of exogenous heparin on neurite outgrowth. Indicated substrata were preincubated with $10 \mu \mathrm{g} / \mathrm{ml}$ of heparin. Nonbound heparin was washed away, and DRG neurons (solid bars) or SC neurons (hatched bars) were cultured on substrata coated with $0.02 \mu \mathrm{M} \mathrm{FN}, 0.2$ $\mu_{\mathrm{M}} 33 / 66 \mathrm{kDa}$ fragments, or $0.5 \mu \mathrm{M}$ peptides FN-C/H I, FN-C/H II, or CS1. Neurite outgrowth was quantitated by visual counting, and is expressed relative to $100 \%$ neurite outgrowth observed for each individual substratum; data represent the mean of two separate experiments, each with triplicate determinations, \pm SEM. Control neurite outgrowth levels were similar to those of Figures 2, 4, and 8.

The sensitivity of neurite outgrowth to heparin was specific, since chondroitin sulfate had virtually no effect on either SC or DRG neurite outgrowth on these substrata (not shown; see Haugen et al., 1990). Considering that intact $\mathrm{FN}$ and the $33 / 66 \mathrm{kDa}$ fragments have multiple sites for cell interaction, these results suggest SC neurite outgrowth is more dependent than DRG neurite outgrowth on the sites within $\mathrm{FN}$ and the $33 / 66 \mathrm{kDa}$ fragments that bind heparin.

As another approach to define the cell surface molecules involved in DRG and SC neurite outgrowth, an antibody that recognizes and blocks the chicken $\beta 1$ integrin subunit, $\mathrm{W} 1 \mathrm{~B} 10$, was added to the cultures (Dr. A. Horwitz, University of Illinois). W1B10 antibody most effectively inhibited DRG neurite outgrowth on CS1-OA (Fig. 7), which binds the a $4 \beta 1$ integrin on hematopoietic cell surfaces (Wayner et al., 1989; Guan and Hynes, 1990; Mould et al., 1990). In contrast, SC neurite outgrowth on CS1-OA was only partially affected by the W1B10 antibody (Fig. 7). W1B10 was least effective on substrata treated with the heparin-binding peptide FN-C/H II-OA (Fig. 7). W1B10 also had no effect on SC neurite outgrowth on substrata treated with the other heparin-binding peptide, FN-C/H I-OA. However, DRG neurite outgrowth on $\mathrm{FN}-\mathrm{C} / \mathrm{H}$ I-OA was partially inhibited by the W1B10 antibody, suggesting that DRG neurons use an integrin component to interact with the FN-C/H I sequence.

In sharp contrast to inhibition by heparin, W1B10 was more inhibitory for DRG neurite outgrowth than for SC neurite outgrowth on all substrata. DRG neurite outgrowth was partially inhibited by W1B10 antibody on the $33 / 66 \mathrm{kDa}$ fragments, which contain the CSI sequence, and FN, which contains multiple $\beta 1$ integrin-binding sites (Fig. 7). SC neurite outgrowth on these substrata was affected by the W1B10 antibody to a lesser extent than was DRG neurite outgrowth. The difference between SC and DRG sensitivity to $\mathrm{W} 1 \mathrm{~B} 10$ antibody was also notable on substrata treated with $\mathrm{CS} 1-\mathrm{OA}$ or FN-C/H I-OA. These data 


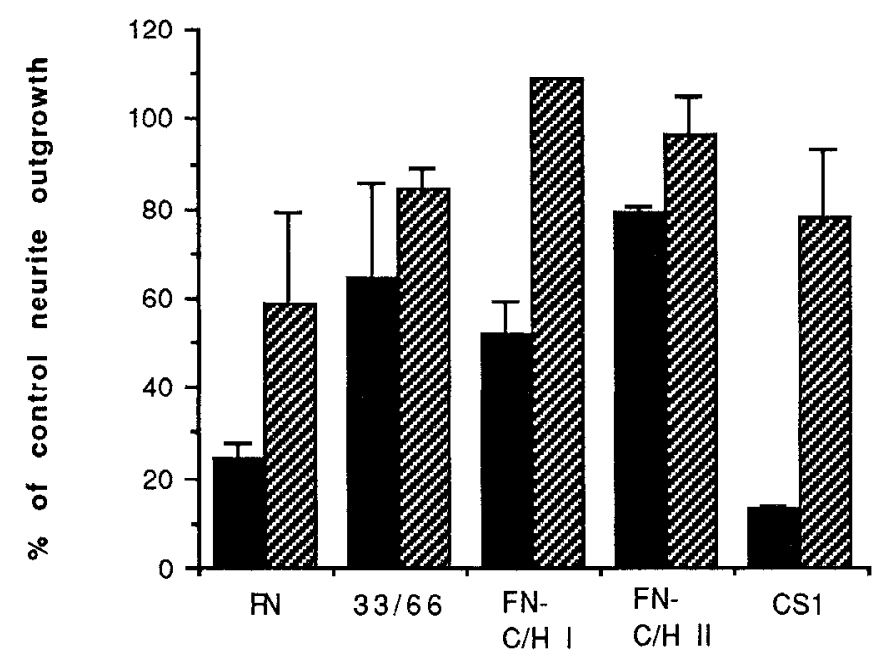

Figure 7. Effect of anti- $\beta 1$ integrin antibody on neurite outgrowth. DRG neurons (solid bars) or SC neurons (hatched hars) were incubated with $20 \mu \mathrm{g} / \mathrm{ml} \mathrm{W1B} 10$ antibody while cultured on substrata coated with $0.02 \mu \mathrm{M} \mathrm{FN}, 0.2 \mu \mathrm{M} 33 / 66 \mathrm{kDa}$ fragments, or $0.5 \mu \mathrm{M}$ peptides $\mathrm{FN}-\mathrm{C} / \mathrm{H}$ I, FN-C/H II, or CS1. Neurite outgrowth was quantitated by visual counting and is relative to the $100 \%$ neurite outgrowth observed for each individual substratum; data represent the mean of two separate experiments, each with triplicate determinations, \pm SEM. Control neurite outgrowth levels were similar to those of Figures 2,4 , and 8.

suggest that DRG neurons rely more on $\beta 1$ integrin-mediated mechanisms for neurite outgrowth than do SC neurons.

Since both heparin-sensitive and $\beta 1$ integrin-mediated mechanisms play a role in neurite outgrowth in response to the C-terminal heparin-binding region of $\mathrm{FN}$, we determined whether these mechanisms might be synergistic by adding both heparin and W1B10 antibodies to the neuronal cultures. For DRG neurite outgrowth on $\mathrm{FN}-\mathrm{C} / \mathrm{H}$ II-OA treated substrata, heparin alone was just as inhibitory as W1B10 and heparin added together (Fig. 8A), suggesting a simple interaction of a cell surface heparin-like proteoglycan with this sequence. In contrast, the addition of both heparin and $\mathrm{W} 1 \mathrm{~B} 10$ synergistically eliminated DRG neurite outgrowth on FN-C/H I-OA, while either one alone had only a partial effect on DRG neurite outgrowth (Fig. $8 A$ ). These results suggest DRG neurite outgrowth on $\mathrm{FN}-\mathrm{C} / \mathrm{H}$ $\mathrm{I}$ is mediated by both heparin-sensitive and $\beta 1$ integrin-mediated mechanisms. Inhibition of DRG neurite outgrowth on CS1$\mathrm{OA}$ and the $33 / 66 \mathrm{kDa}$ fragments by both heparin and W1B10 was not additive in any significant manner (Fig. $6 \mathrm{~A}$ ), indicating that DRG neurons interact with the CS1 sequence and the 33/ $66 \mathrm{kDa}$ C-terminal heparin-binding fragments using predominantly a $\beta 1$ integrin-mediated mechanism.

As was noted for DRG neurite outgrowth, SC neurite outgrowth on FN-C/H II-OA can be totally accounted for by a heparin-sensitive mechanism (Fig. $8 B$ ). In sharp contrast to DRG neurite outgrowth, the inhibition of SC neurite outgrowth on $\mathrm{FN}-\mathrm{C} / \mathrm{H}$ I-OA by heparin and anti- $\beta 1$ integrins was not additive, since heparin alone had the greatest effect on SC neurite outgrowth (Fig. $8 B$ ). Also in contrast to DRG neurite outgrowth, $\mathrm{SC}$ neurite outgrowth on a $33 / 66 \mathrm{kDa}$ treated substratum was not inhibited by W1B10 antibody, but was effectively inhibited by heparin alone (Fig. $8 B$ ), indicating that $\mathrm{SC}$ neurons rely predominantly on heparin-sensitive mechanisms for neurite outgrowth on the $33 / 66 \mathrm{kDa}$ heparin-binding fragments.
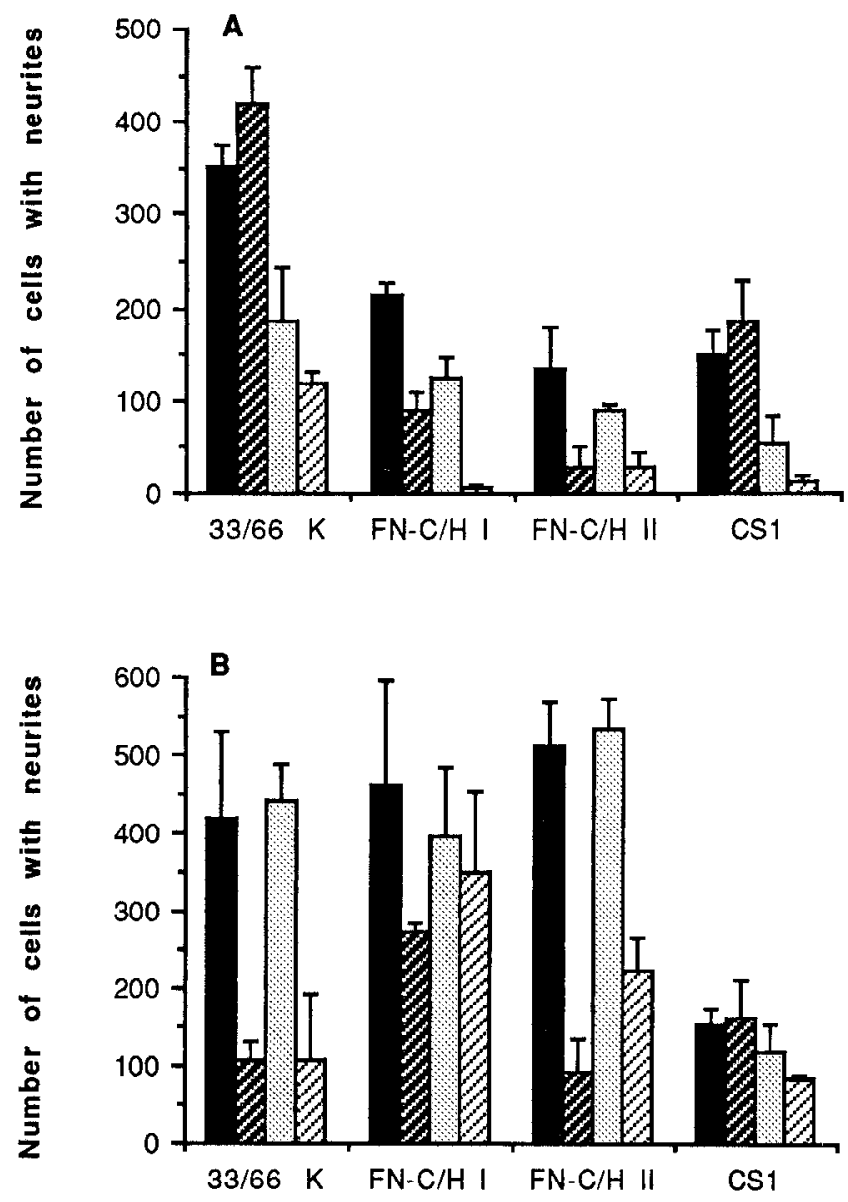

Figure 8. Effect of both exogenous heparin and anti- $\beta 1$ integrin antibodies on neurite outgrowth. DRG neurons $(A)$ and SC neurons $(B)$ were cultured with inhibitors on substrata coated with $0.2 \mu \mathrm{M} \mathrm{33/66}$ $\mathrm{kDa}$ fragments, $2 \mu \mathrm{M} \mathrm{FN}-\mathrm{C} / \mathrm{H}$ I or FN-C/H II, or $0.5 \mu \mathrm{M}$ CS1. Cultures were treated with the following inhibitors: control (no inhibitors, solid bars), $10 \mu \mathrm{g} / \mathrm{ml}$ heparin (dark hatched bars), $20 \mu \mathrm{g} / \mathrm{ml} \mathrm{W1B10}$ antibody (stippled bars), or $10 \mu \mathrm{g} / \mathrm{ml}$ heparin $+20 \mu \mathrm{g} / \mathrm{ml} \mathrm{W1B10} \mathrm{(light} \mathrm{hatched}$ bars). Neurite outgrowth was quantitated by counting, and represents the mean of triplicate determinations, \pm SEM.

\section{Discussion}

The purpose of the present study was to investigate the molecular basis for differences in central and peripheral neuronal responses to the FN C-terminal cell and heparin-binding fragment. In this study, we demonstrate clear differences in CNS and PNS neurite outgrowth with respect to preference for polypeptide sequences from this region of $\mathrm{FN}$ as substrata on which to extend neurites. In general, SC neurons preferred heparin-binding substrata such as the $33 / 66 \mathrm{kDa}$ fragments of $\mathrm{FN}$ and the peptide FN-C/H II, while DRG neurons preferred integrin-binding substrata such as the $75 \mathrm{kDa} F N$ fragment and the peptide CS1. CNS and PNS neurons also differed in that SC neurons were more sensitive to inhibition by soluble heparin, while DRG neurons were more affected by anti- $\beta 1$ integrin antibodies. We propose that CNS and PNS neurons differ in their use of cell surface molecules when extending neurites in response to FN.

This study also indicates that neurons use multiple sequences within the C-terminal cell and heparin-binding fragment of FN to extend neurites. Buth SC and DRG neurons extended neurites on FN-C/H II, FN-C/H I, and CS1. Further, with the exception 
of soluble CS1 in SC cultures, each of these peptides in solution partially inhibited neurite outgrowth on the $33 / 66 \mathrm{kDa}$ fragment, indicating that neurons interact directly with these sequences within the context of the larger $33 / 66 \mathrm{kDa}$ fragments. FN-C/H II was an especially effective substratum for neurite outgrowth. These and previous results identifying FN-C/H II as a promoter of neuroblastoma adhesion and spreading (Haugen et al., 1990) suggest that FN-C/H II is an important neural cell recognition sequence within FN. Second, our results identify $\mathrm{FN}-\mathrm{C} / \mathrm{H} \mathrm{I}$ as a neurite-promoting sequence. $\mathrm{FN}-\mathrm{C} / \mathrm{H}$ I has also been shown to promote melanoma adhesion and spreading (McCarthy et al., 1990), indicating an important role for this sequence in cellular responses to $\mathrm{FN}$ by a variety of cell types. Finally, CSI was also a neurite-promoting sequence, confirming the results of Humphries et al. (1988) for DRG neurons. The observation that neurons use three independent sequences for neurite outgrowth is consistent with a growing body of evidence suggesting that cellular interactions with FN and the C-terminal cell and heparin-binding fragment involve multiple sites (McCarthy et al., 1986, 1990; Humphries et al., 1987, 1988; Mugnai et al., 1988; Obara et al., 1988; Haugen et al., 1990; Lewandowska et al., 1990).

While both SC and DRG neurons extended neurites on the three peptides tested, they differed in the effectiveness of their response to low concentrations of each of these peptides. For example, SC neurons responded to concentrations of $\mathrm{FN}-\mathrm{C} / \mathrm{H}$ II nearly an order of magnitude lower than those required to elicit the same DRG response. In contrast, DRG neurons responded to much lower concentrations of CS1 than did SC neurons. Further, SC neurons were most inhibited by soluble FN-C/H II, while DRG neurons were most inhibited by soluble CS1. Such differences in SC and DRG sensitivity to different sequences suggest there may be differences between DRG and $\mathrm{SC}$ neurons at the receptor level. One possibility is that DRG and SC neurons differ in the expression of particular cell surface receptors that interact with the $\mathrm{FN}-\mathrm{C} / \mathrm{H}$ II and the CSI sequences.

Onc way in which SC and DRG neurons may differ is with respect to their use of the integrin receptors for FN. Our data suggest that DRG neurons rely extensively on $\beta 1$ integrins for their interactions with FN and the $33 / 66 \mathrm{kDa}$ fragments. DRG neurons preferred integrin-binding substrata and were more affected by the addition of anti- $\beta 1$ integrin antibodies than by heparin. Additionally, anti- $\beta 1$ integrin antibodies effectively inhibited DRG neurite outgrowth on the $33 / 66 \mathrm{kDa}$ fragments. The behavior of SC neurons was in sharp contrast to that of DRG neurons. SC neurons extended neurites on the $a 4 \beta 1$ integrin-binding ligand, CS1, but much less effectively than DRG neurons. Additionally, unlike DRG neurite outgrowth, SC neurite outgrowth on the $33 / 66 \mathrm{kDa}$ fragments was unaffected by soluble CS1. Further, SC neurite outgrowth was inhibited by the anti- $\beta 1$ integrin antibody to a much lesser extent than was DRG neurite outgrowth. One possible explanation for these differences is that SC and DRG ncurons differ quantitatively in expression of $\beta 1$ integrin complexes. Support for this idea comes from immunofluorescence studies with anti- $\beta 1$ integrin antibodies, in which SC staining was less intense than DRG staining (Letourneau et al., 1988, using a polyclonal antibody that recognizes the chicken $\beta 1$ integrin; P. C. Letourneau, unpublished observations using $\mathrm{W} 1 \mathrm{~B} 10$ antibody). Alternatively, the relative inability of the W1B10 antibody to inhibit SC neurite outgrowth may suggest that $\mathrm{SC}$ neurons interact with the integrin-binding sequences in $\mathrm{FN}$, such as CS1, using a $\beta$-subunit different from $\beta 1$ (Holzmann et al., 1989). A further possibility is that there are differences between SC and DRG $\beta 1$ integrins in activation or conformation that affect ligand binding, such as those noted by Neugebauer and Reichardt (1991).

SC and DRG neurons may also rely on a second class of receptors, cell surface proteoglycans, for neurite outgrowth on FN. Cell surface proteoglycans are implicated by several studies as mediators of cell-matrix interactions (Laterra et al., 1983; Rapraeger and Bernfield, 1983; Woods et al., 1985; Mugnai et al., 1988; Saunders and Bernfield, 1988; Culp, 1989; LeBaron et al., 1989). Our findings that SC neurons prefer heparin-binding sequences in FN and that SC neurite outgrowth is extremely sensitive to inhibition by heparin suggest SC neurons are more dependent on cell surface heparin-like proteoglycan molecules than on integrins for interactions with FN. A role for a cell surface proteoglycan in SC neurite outgrowth is further supported by the observations that only heparin, and not anti- $\beta 1$ integrin antibodies, affected SC neurite outgrowth on the 33/66 $\mathrm{kDa}$ fragments. DRG neurons may also make use of a cell surface heparin-like proteoglycan, since they extended neurites on the heparin-binding peptides $\mathrm{FN}-\mathrm{C} / \mathrm{H}$ II and FN-C/H I and since DRG neurite outgrowth was partially affected by exogenous heparin. However, DRG neurite outgrowth on FN-C/H I was inhibited by heparin to a lesser extent than was SC neurite outgrowth. Cell surface proteoglycans are likely to play an important role in neurite outgrowth, especially in the CNS.

DRG neurite outgrowth on FN-C/H I may involve both a $\beta 1$ integrin and a cell surface proteoglycan. DRG neurite outgrowth on this peptide was sensitive to heparin, consistent with the described heparin-binding properties of $\mathrm{FN}-\mathrm{C} / \mathrm{H}$ I (McCarthy et al., 1988, 1990), but was also sensitive to anti- $\beta 1$ integrin antibodies. Treatment with both heparin and anti- $\beta 1$ integrin antibodies totally eliminated DRG neurite outgrowth on FN$\mathrm{C} / \mathrm{HI}$, indicating that DRG neurite outgrowth relies on integrinmediated and heparin-sensitive mechanisms in an additive or synergistic manner. Neugebauer et al. (1988) and Tomaselli et al. (1988) have also noted that neurons make use of other types of cell surface molecules in concert with integrins when extending neurites on various substrata.

The results presented here suggest that neurons interact with multiple sites in the FN molecule using both integrin and heparin-like proteoglycan receptors on their surfaces. Cell-specific differences at the receptor level could have profound effects on how a cell interacts with complex molecules that contain multiple sites, such as FN, and could explain the differences noted between SC and DRG neurons. It is not yet known exactly how the differences between CNS and PNS neurite outgrowth on these FN sequences are involved in neuronal development, but it is likely these cell-specific differences have important consequences for the complex and diverse developmental events in the CNS and PNS.

\section{References}

Akers RM, Mosher DF, Lilicn JE (1981) Promotion of retinal neurite outgrowth by substratum-bound fibronectin. Dev Biol 86:179-188.

Bauminger S, Wilchek M (1980) The use of carbodiimides in the preparation of immunizing conjugates. Methods Enzymol 70:151159.

Bozyczko D, Horwitz AF (1986) The participation of a putative cell surface receptor for laminin and fibronectin in peripheral neurite extension. J Neurosci 6:1241-1251. 
Bronner-Fraser M (1986) An antibody to a receptor for fibronectin and laminin perturbs cranial neural crest development in vivo. Dev Biol 117:528-536.

Buck CA, Horwitz AF (1987) Cell surface receptors for extracellular matrix molecules. Annu Rev Cell Biol 3:179-205.

Carbonetto S, Gruver MM, Turner DC (1983) Nerve fiber growth in culture on fibronectin, collagen, and glycosaminoglycan substrates. J Neurosci 3:2324-2335.

Chelberg MK, Tsilibary EC, Hauser AJ, McCarthy JB (1989) Type IV collagen-mediated melanoma cell adhesion and migration: involvement of multiple, distinct domains of the collagen molecule. Cancer Res 49:4796-4802.

Chun JJM, Shatz CJ (1988) A fibronectin-like molecule is present in the developing cat cerebral cortex and is correlated with subplate neurons. J Cell Biol 106:857-872.

Culp LA, Mugnai G, Lewandowska K, Vallen EA, Kosir MA, Houmiel KL (1989) Heparan sulfate proteoglycans of Ras-transformed 3T3 or neuroblastoma cells. Ann NY Acad Sci 556:194-216.

Dedhar S (1990) Integrins and tumor invasion. Bioessays 12:583-590.

Dodd J, Jessell TM (1988) Axon guidance and the patterning of neuronal projections in vertebrates. Science 242:692-699.

Duband JL, Thiery JP (1982a) Distribution of fibronectin in the early phase of avian cephalic neural crest cell migration. Dev Biol 93:308323

Duband JL, Thiery JP (1982b) Appearance and distribution of fibronectin during chick embryo gastrulation and neurulation. Dev Biol 94:337-350.

Dufour S, Duband JL, Humphries MJ, Obara M, Yamada KM, Thiery JP (1988) Attachment, spreading, and locomotion of avian neural crest cells are mediated by multiple adhesion sites on fibronectin molecules. EMBO J 7:2661-2671.

Furcht LT (1981) Structure and function of the adhesive glycoprotein fibronectin. In: Modern cell biology (Satir B, ed), pp 53-117. New York: Liss.

Guan J-L, Hynes RO (1990) Lymphoid cells recognize an alternatively spliced segment of fibronectin via the integrin receptor a4 $\beta 1$. Cell 60 : 53-61.

Gunderson RW (1987) Response of sensory neurites and growth cones to patterned substrata of laminin and fibronectin in vitro. Dev Biol $121: 423-431$.

Hall DE, Neugebauer KM, Reichardt LF (1987) Embryonic neural retinal cell response to extracellular matrix proteins: developmental changes and effects of the cell substratum attachment antibody (CSAT). J Cell Biol 104:623-634.

Haugen PK, McCarthy JB, Skubitz APN, Furcht LT, Letourneau PC (1990) Recognition of the A chain carboxy-terminal heparin binding region of fibronectin involves multiple sites: two contiguous sequences act independently to promote neural cell adhesion. J Cell Biol 111: 2733-2745.

Herndon ME, Lander AD (1990) A diverse set of developmentally regulated proteoglycans is expressed in the rat central nervous system. Neuron 4:949-961.

Holzmann B, McIntyre BW, Weissman IL (1989) Identification of a murine Pcyer's patch-specific lymphocyte homing receptor as an integrin molecule with an alpha chain homologous to human VLA-4a. Cell 56:37-46.

Horwitz A, Duggan K, Greggs R, Decker C, Buck C (1985) The cell substrate attachment (CSAT) antigen has properties of a receptor for laminin and fibronectin. J Cell Biol 101:2134-2144.

Humphries MJ (1990) The molecular basis and specificity of integrinligand interactions. J Cell Sci 97:585-592.

Humphries MJ, Komoriya $\Lambda$, Akiyama SK, Olden K, Yamada KM (1987) Identification of two distinct regions of the type III connecting segment of human plasma fibronectin that promote cell type-specific adhesion. J Biol Chem 262:6886-6892.

Humphries MJ, Komoriya A, Akiyama SK, Olden K, Yamada KM (1988) Neurite extension of chicken peripheral nervous system neurons on fibronectin: relative importance of specific adhesion sites in the central cell-binding domain and the alternatively spliced type III connecting segment. J Cell Biol 106:1289-1297.

Hynes R (1987) Integrins: a family of cell surface receptors. Cell 48: 549-554.

Izzard CS, Radinsky R, Culp LA (1986) Substratum contacts and cytoskeletal reorganization of BALB/c $3 T 3$ cells on a cell-binding fragment and heparin-binding fragments of plasma fibronectin. Exp Cell Res 165:320-336.

Kornblihtt AR, Umezawa K, Vibe-Pedersen K, Baralle FE (1985) Primary structure of human fibronectin: differential splicing may generate at least 10 polypeptides from a single gene. EMBO J 4:17551759.

Laterra J, Silbert JE, Culp LA (1983) Cell surface heparan sulfate mediates some adhesive responses to glycosaminoglycan-binding matrices, including fibronectin. J Cell Biol 96:112-123.

LeBaron RG, Hook A, Esko JD, Gay S, Hook M (1989) Binding of heparan sulfate to type $\mathrm{V}$ collagen. A mechanism of cell-substratum adhesion. J Biol Chem 264:7950-7956.

Letourneau PC (1975) Possible roles for cell-to-substratum adhesion in neuronal morphogenesis. Dev Biol 44:77-91.

I etourneau PC (1985) Axonal growth and guidance. In: Molecular bases of neural development (Edelman GM, Gall WE, Cowan WM, eds), pp 269-294. New York: Wiley.

Letourneau PC (1989) Nerve cell shape. In: Cell shape: determinants, regulation, and regulatory role, pp 247-289. New York: Academic.

Letourneau PC, Shattuck TA (1989) Distribution and possible interactions of actin-associated proteins and cell adhesion molecules of nerve growth cones. Development 105:505-519.

Letourneau PC, Pech IV, Rogers SL, Palm SL, McCarthy JB, Furcht LT (1988) Growth cone migration across extracellular matrix components depends on integrin, but migration across glioma cells does not. J Neurosci Res 21:286-297.

Lewandowska K, Balza E, Zardi L, Culp LA (1990) Requirement for two different cell-binding domains in fibronectin for neurite extension of neuronal derivative cells. J Cell Sci 95:75-83.

Liao NS, St John J, McCarthy JB, Furcht LT, Cheung HT (1989) Adhesion of lymphoid cells to the carboxyl terminal heparin-binding domains of fibronectin. Exp Cell Res 181:348-361.

Margolis RU, Margolis RK (1989) Nervous tissue proteoglycans. Dev Neurosci 11:276-288.

McCarthy JB, Hagen ST, Furcht LT (1986) Human fibronectin contains distinct adhesion- and motility-promoting domains for metastatic melanoma cells. J Cell Biol 102:179-188.

McCarthy JB, Chelberg MK, Mickelson DJ, Furcht LT (1988) Localization and chemical synthesis of fibronectin peptides with melanoma adhesion and heparin binding activities. Biochemistry 27:13801388.

McCarthy JB, Skubitz APN, Zhao Q, Yi X-Y, Mickelson DJ, Klein DJ, Furcht LT (1990) RGD-independent cell adhesion to the carboxyterminal heparin-binding fragment of fibronectin involves heparindependent and -independent activities. J Cell Biol 110:777-787.

Mould AP, Wheldon LA, Komoriyama A, Wayner EA, Yamada KM, Humphries MJ (1990) Affinity chromatographic isolation of the melanoma adhesion receptor for the IIIcs region of fibronectin and its identification as the integrin a4ß1. J Biol Chem 265:4020-4024.

Mugnai G, Lewandowska K, Carnemolla B, Zardi L, Culp LA (1988) Modulation of matrix adhesive responses of human neuroblastoma cells by neighboring sequences in the fibronectins. J Cell Biol 106: 931-943.

Neugebauer KM, Reichardt LF (1991) Cell-surface regulation of $\beta 1$ integrin activity on developing retinal neurons. Nature 350:68-71.

Neugebauer KM, Tomaselli KJ, Lilien J, Reichardt LF (1988) N-cadherin, NCAM, and integrins promote retinal neurite outgrowth on astrocytes in vitro. J Cell Biol 107:1177-1187.

Obara M, Kang MS, Yamada KM (1988) Site-directed mutagenesis of the cell-binding domain of human fibronectin: separable, synergistic sites mediate adhesive function. Cell 53:649-657.

Pierschbacher MD, Ruoslahti E (1984) The cell attachment activity of fibronectin can be duplicated by small synthetic fragments of the molecule. Nature 309:30-33.

Pytela R, Peirschbacher MD, Ruoslahti E (1985) Identification and isolation of a $140 \mathrm{kd}$ cell surface glycoprotein with properties expected of a fibronectin receptor. Cell 40:191-198.

Rapraeger AC, Bernfield M (1983) An integral membrane proteoglycan is capable of binding components of the cytoskeleton and the extracellular matrix. In: Extracellular matrix, pp 265-269. New York: Academic.

Reichardt LF, Tomaselli KJ (1991) Extracellular matrix molecules and their receptors: functions in neural development. Annu Rev Neurosci 14:531-570.

Rogers SL, Letourneau PC, Palm SL, McCarthy J, Furcht LT (1983) 
Neurite extension by peripheral and central nervous system neurons in response to substratum-bound fibronectin and laminin. Dev Biol 98:212-220.

Rogers SL, McCarthy JB, Palm SL, Furcht LT, Letourneau PC (1985) Neuron-specific interactions with two neurite-promoting fragments of fibronectin. J Neurosci 5:369-378.

Rogers SL, Letourneau PC, Peterson BA, Furcht LT, McCarthy IB (1987) Selective interaction of peripheral and central nervous system cells with two distinct cell-binding domains of fibronectin. J Cell Biol 105:1435-1442.

Rogers SL, Letourneau PC, Pech IV (1989) The role of fibronectin in neural development. Dev Neurosci 11:248-265.

Ruoslahti E (1988a) Fibronectin and its receptors. Annu Rev Biochem $57: 375-413$.

Ruoslahti E (1988b) Structure and biology of proteoglycans. Annu Rev Cell Biol 4:229-255.

Sanes JR (1989) Extracellular matrix molecules that influence neural development. Annu Rev Neurosci 12:491-516.

Saunders S, Bernfield M (1988) Cell surface proteoglycan binds mouse mammary epithelial cells to fibronectin and behaves as a receptor for interstitial matrix. I Cell Biol 106:423-430.

Stewart GR, Pearlman AL (1987) Fibronectin-like immunoreactivity in the developing cerebral cortex. J Neurosci 7:3325-3333.
Stewart JM, Young JD (1984) Solid phase peptide synthesis, 2d ed. Rockford, IL: Pierce Chemical Co.

Tomaselli K, Neugebauer KM, Bixby JL, Lilien J, Reichardt LF (1988) $\mathrm{N}$-cadherin and integrins: two receptor systems that mediate neuronal process outgrowth on astrocyte surfaces. Neuron 1:33-43.

Visser MR, Vercellotti GM, McCarthy JB, Goodman JL, Herbst TJ, Furcht LT, Jacob HS (1989) Herpes simplex virus inhibits endothelial cell attachment and migration to extracellular matrix proteins. Am J Pathol 134:223-230.

Waite KA, Mugnai G, Culp LA (1987) A second cell-binding domain on fibronectin (RGDS-independent) for neurite extension of human neuroblastoma cells. Exp Cell Res 169:311-327.

Wayner EA, Garcia-Pardo A, Humphries MJ, McDonald JA, Carter WG (1989) Identification and characterization of the T lymphocyte adhesion receptor for an alternative cell attachment domain (CS-1) in plasma fibronectin. J Cell Biol 109:1321-1330.

Woods A, Couchman JR, Hook M (1985) Heparan sulfate proteoglycans of rat embryo fibroblasts. J Biol Chem 260:10872-10879.

Yamada KM (1989) Fibronectins: structure, functions and receptors. Curr Opin Cell Biol 1:956-963.

Zaremba S, Guimaraes A, Kalb RG, Hockfield S (1989) Characterization of an activity-dependent, neuronal surface proteoglycan identified with monoclonal antibody Cat-301. Neuron 2:1207-1219. 